To cite: UO Egbai \& JO Chimakonam 'Protecting the rights of victims in transitional justice:

\title{
Protecting the rights of victims in transitional justice: An interrogation of amnesty
}

\section{Uti Ojah Egbai*}

Senior Lecturer, Department of Philosophy, University of Calabar, Nigeria https://orcid.org/0000-0003-1993-2759

\section{Jonathan O Chimakonam*}

Senior Lecturer, Department of Philosophy, University of Pretoria, South Africa https://orcid.org/0000-0001-8913-1434

\section{Summary}

The authors argue in this article that some categories of amnesty programmes, such as 'blanket' and 'self-granted amnesties' that bar the prosecution of perpetrators, have not been very helpful in the protection of the rights of victims in transitional justice. They contend, before embarking on widespread abuses of human rights since the post-ICJ era, that most perpetrators, especially dictators, often are aware of the legal odds but feel confident that if their regimes collapse, they would press for amnesty at least in return for a transitional process involving cooperation, surrender, confession, reparation and reconciliation. The Chilean, Peruvian and Sri Lankan cases have become citeable precedents. This reliance presents these categories of amnesty as unjust instruments of transitional justice. The article proposes a rule of law-based transitional justice that will involve an adjustment in the international law as a viable alternative to some amnesty programmes that appear to shield perpetrators from justice.

Key words: transitional justice; amnesty; rule of law; truth commissions; international law

* PhD (Calabar); drutiegba@gmail.com

** PhD (Calabar); jonathan.okeke@up.ac.za 


\section{Introduction}

Justice may be conceived elementarily as allowing the law to take its full course within its jurisdiction in matters regarding rewards, punishment and the distribution of goods and opportunities. The notions of blanket and self-granted amnesties, which are some of the strategies of transitional justice, simply state that the law should take a much-reduced course, if at all. Where then is the justice component in the programme called transitional justice? This question might be regarded as 'thinking out loud' and, indeed, may seem of little practical importance in our fast-advancing ideas about justice, but our justice programmes can hardly be complete without a retributive component. Transitional justice that admits of a type of amnesty which shields perpetrators from punishment may simply be robbing Peter to pay Paul, and this goes against the fundamental idea of justice as a programme that rewards legally correct actions and punishes illegal ones.

In this article we intend to work with the elementary conception of justice proffered above, and as such the article does not consider the well-known historical controversies associated with the definition of the term, beginning from Plato to Rawls and Nozick. ${ }^{1}$ Despite the many differing views about justice, one gleans from all these that justice has legal and ethical components. Maduabuchi aptly observes: "The term "justice" is as old as man. The minds of the masses, the oppressed, the down-trodden and the slaves are yearning for justice. Justice is a legal, ethical and ontological term. It is a common and living concept. The question of justice is a perennial one. ${ }^{2}$ Here, we do not intend to stretch the question of justice further, but strictly wish to study some of its practical dimensions in the forms of instituting, maintaining and applying the rule of law. The legality of justice is in the application of the rule of law and its ethical dimension lies in doing this without bias and compromise.

In a transitional justice programme, which is a strategy for moving a society from a period of chaos to that of peace, cases of abuse and human rights violations are handled in ways that should soothe wounds, calm nerves, expose secrets, repair damages, redress injustices, reconcile opponents and bring stability to a volatile context. The challenge in the transitional justice programme is that the rule of law is easily set aside. The rights of victims to justice might be grossly violated by the state when certain types of amnesty programmes that shield criminals from prosecution are deployed. The international

1 See Plato The republic of Plato trans A Bloom (1991); R Nozick Anarchy, state and utopia (1974); J Rawls 'Justice as fairness: Political not metaphysical' (1985) 14 Philosophy and Public Affairs 223; J Rawls A theory of justice (1999).

2 M Dukor 'Conceptions of justice' (1997) 24 Indian Philosophical Quarterly 497. 
criminal and human rights laws require states to investigate and prosecute all cases of abuse and human rights violations. ${ }^{3}$

However, the immediate question is whether strategies of transitional justice should shield perpetrators or protect the rights of victims to justice. In this article we argue for the latter. Our inquiry focuses on showing that broad-based amnesties, such as blanket and self-granted amnesties, vitiate the rule of law and obstruct the course of justice. Our position is to criticise these categories of amnesty programmes that offer broad-based coverage (and to elevate criminal prosecution) after providing some of its strongest arguments. Our proposal is a rule of law-based alternative that involves limited amnesties, if at all. We begin with an elementary clarification of our concepts.

\section{What is transitional justice?}

Two words make up this concept, namely, 'transition', meaning to move from one point to another or, for our purpose, from one governmental regime to another; and 'justice', meaning, for our purpose, to abide by the rule of law with regard to reward, punishment and distribution of resources. Transitional justice, therefore, describes the type of justice that is sought in order to help bring about a peaceful transition from one regime (usually a repressive regime) to another (usually a democratic regime). Indeed, many scholars have offered different but related definitions of transitional justice. According to the International Centre for Transitional Justice, ${ }^{4}$

[t]ransitional justice is a response to systematic or widespread violations of human rights. It seeks recognition for victims and promotion of possibilities for peace, reconciliation and democracy. Transitional justice is not a special form of justice but justice adapted to societies transforming themselves after a period of pervasive human rights abuse.

The foregoing is also similar to the definition offered by the United Nations (UN) which conceives it as 'the full range of processes and mechanisms associated with a society's attempt to come to terms with a legacy of large-scale past abuses, in order to ensure accountability, serve justice and achieve reconciliation'. ${ }^{5}$ What may be gleaned from the definitions above is that an overemphasis on peace and reconciliation may form the necessary grounds for states to introduce broad-based amnesty programmes for perpetrators of largescale human right abuses and crimes against humanity. When this

3 M Freeman \& P Hayner 'Truth-telling' in D Bloomfield et al (eds) Reconciliation after violent conflict: A handbook (2003) 137.

4 International Centre for Transitional Justice 'What is transitional justice?' http:// www.ictj.org (accessed 5 November 2015).

$5 \quad \mathrm{~K}$ Annan The rule of law in conflict and post-conflict societies (2004). 
occurs, the ideas of accountability and justice are vitiated. Laplante, ${ }^{6}$ for example, relates how this emphasis led the corrupt and compromised government in Peru to legalise impunity through amnesty. She also discusses how the widespread impunity in Peru, which almost sidelined criminal justice in the application of transitional justice, soon led to international intervention. This intervention came in the form of the strengthening of human rights laws, the development of international criminal law, and a reduction of a state's authority at legislating immunity measures such as amnesty. We will revisit the issue of amnesty leading to large-scale human rights abuses later in the article.

\section{How broad-based amnesty programmes scuttle transitional justice}

According to Shalev, ${ }^{7}$ there are approximately five known categories of amnesty programmes:

- blanket amnesty which covers a broad range of crimes (a good example is Sri Lanka's Indemnity Act of1982);

- conditional amnesty, which provides conditions or criteria under which certain individuals could be absolved from prosecution (a typical example being the South African case);

- de facto amnesty as in the case of Argentina's Ley de Punto Final $(1986)^{8}$ which does not prohibit amnesty but limits it;

- disguised amnesty which depends on other laws for their interpretation and implementation, such as the Ouagadougou Political Agreement (2007) which could be interpreted for implementation based on different provisions in Ordinance 2007475; and

- the notorious self-amnesty which is pardon granted to itself by a ruling government for its crimes (for example, the Peruvian case).

Amnesty has been a part of humanity's long political history that dates back to approximately 403 BC. ${ }^{9}$ It has been invoked in different contexts for different purposes. In ancient Greece Thrasybulus invoked it to end a lingering conflict. ${ }^{10}$ In Peru it was invoked to legalise impunity. ${ }^{11}$ In Liberia it was invoked to attain transition from a

6 JL Laplante 'Outlawing amnesty: The return of criminal justice in transitional justice schemes' (2009) 49 Virginia Journal of International Law 915.

7 I Shalev 'EIP explainer: Amnesties' (2015) European Institute of Peace http:// www.eip.org/en/news-events/eip-explainer-amnesties (accessed 20 September 2019).

8 As above.

9 GR Teitel Transitional justice (2000) 53.

10 RJ Buck Thrasybulus and the Athenian democracy: The life of an Athenian statesman (1998) 120.

11 Laplante (n 6). 
totalitarian to a democratic regime. ${ }^{12}$ However, the most powerful arguments in support of amnesty are that amnesty encourages a perpetrator to 'confess' his crimes and show 'remorse' for them. These gestures help the victim to 'heal' and thus to show 'forgiveness'. Together they provide adequate grounds for 'reconciliation' which then brings about 'peace'. However, what should be pointed out here is that the problem with programmes that emphasise and prioritise confessions, forgiveness and reconciliation over criminal prosecution is that they deny victims justice by shielding perpetrators in a transitional justice process.

Granted that transitional justice processes are based on the thinking that victims of atrocities and their societies need to know the truth about what had transpired, it falls to Truth Commissions to bring this about. Sooka supports the imperative of truth commissions in providing the framework for true reconciliation and transitional justice in post-conflict zones. ${ }^{13}$ However, Cassel argues also that the right to know the truth is not autonomous but is 'subsumed in the right of victims and families to obtain clarification of the facts through judicial investigation and adjudication'. ${ }^{14}$ This right to know is also enshrined in international law, as Villalba acknowledges. ${ }^{15}$

What can be established from the above is that truth commissions that offer broad-based amnesty may not be the only way to unearth the truth about what happened in repressive times. A thorough judicial process of criminal justice can also achieve this. Laplante cites the case of the Nuremburg trials as a credible example in which the criminal justice procedure makes amnesty less captivating. ${ }^{16}$ On the strength of this, we will interrogate amnesty as an immunity measure in the next part.

\section{An interrogation of amnesty as an instrument of transitional justice}

Some people think, perhaps correctly, that amnesties are very effective in revealing the hidden truths. ${ }^{1}$ Perhaps it is helpful to be optimistic, especially when the programme is applied in a transition from a troubled to a peaceful time. Undoubtedly, a documented perpetrator who would inevitably face criminal prosecution most likely

\footnotetext{
12 Laplante 66-68.

13 Y Sooka 'Dealing with the past and transitional justice: Building peace through accountability' (2006) 88 International Review of the Red Cross 311.

14 D Cassel Victims unsilenced: The Inter-American human rights system and transitional justice in Latin America (2007) 160.

15 SC Villalba 'Transitional justice: Key concepts, processes and challenges' Briefing paper (IDCR-BP-07/11) Institute for Democracy and Conflict Resolution (IDCR) (2011) 7.

16 Laplante (n 6) 918.

17 Villalba (n 15) 4.
} 
will embrace the promise of amnesty and confess his crimes. The instinct of self-preservation explains this choice. Indeed, examples abound across history where this measure has led to the unmasking of many truths that probably would not have been known. Hayner ${ }^{18}$ relates a particularly strong case in the South African Truth and Reconciliation Commission (TRC) about three men who disappeared in the 1980s. An official police investigation revealed no clues, but at the TRC a former police officer, who had applied for and received amnesty, confessed the truth about their disappearance. The police officer along with colleagues had kidnapped and killed the men, then roasted their bodies for six hours until they turned into ash before throwing their ash into the Fish River. As horrendous as that was, the report helped some of the victims' families to obtain closure in their loss and further made the programme of reconciliation significant to national healing.

However, despite these clear advantages that amnesty as an instrument of transitional justice affords, there are strong arguments vitiating it as a morally and politically correct principle. For example, arguments have been raised about amnesty granting a freedom ticket to criminals; $^{19}$ about perpetrators under amnesty not showing remorse or telling their hideous story in a triumphant tone; about amnesty violating international criminal and human rights laws; ${ }^{20}$ about it denying victims their rights to justice; about it providing protection to perpetrators and denying same to victims, ${ }^{21}$ and so forth. Indeed, sensitive observations such as these bring amnesty seriously into question. It is largely for this reason that Freeman and Hayner $^{22}$ observe that amnesty is 'inconsistent with a state's obligation under international law to punish perpetrators of serious human rights crimes'. Following on this, Dugard declares that 'amnesty is no longer accepted as the natural price to be paid for transition from repression to democracy'. ${ }^{23}$ This raises the question of what amnesty is.

Amnesty is not an acquittal, in that one no longer is guilty. Despite being granted amnesty, a perpetrator is not cleared of the crimes of which he has been accused. Amnesty is not a verdict of innocence or of guilt. It is not proof that one is guilty or that one is innocent. It is turning a blind eye to the law in pursuit of the immediate goal of

18 P Hayner Unspeakable truths: Transitional justice and the challenge of truth commissions (2011) 22.

19 International Centre for Transitional Justice 'Amnesty must not equal impunity, 2009 DRC amnesty law', http://www.ictj.org (accessed 5 November 2015).

20 Y Naqvi 'Amnesty for war crimes: Defining the limits of international recognition' (2003) 85 International Review of the Red Cross 583.

21 AR Wilson The politics of truth and reconciliation in South Africa: Legitimising the post-apartheid state (2001) 167-172.

22 Freeman \& Hayner (n 3) 137.

23 J Dugard 'Dealing with crimes of a past regime: Is amnesty still an option?' (1999) 12 Leiden Journal of International Law 1001. 
peace and stability. The conditions of amnesty are not the same as the conditions of ransom. A perpetrator does not confess his crimes before receiving amnesty. Amnesty is not even a law-keeping practice in light of national and international criminal and human rights laws, but rather a law-breaking practice. It means setting aside the rule of law to do that which is considered immediately profitable as against that which is legally and strategically correct or even morally right.

Gardner defines amnesty as 'a pardon extended by the government to a group or class of persons, usually for a political offense; the act of a sovereign power officially forgiving certain classes of persons who are subject to trial but have not yet been convicted'. ${ }^{24}$ The foremost exercise of amnesty in the history of human civilisation, as indicated earlier, can be traced back to around 404 BC when the Greek general Thrasybulus offered amnesty to some remnants of the Athenian oligarchy. ${ }^{25}$ Ever since, amnesty has appeared to be a common and acceptable practice at the end of warfare and conflict. However, in the post-World War II era, following the example of the Nuremburg trials and the post-Cold War era, following a sophistication in international criminal and human rights laws, the wisdom of amnesty is widely being questioned. The case of South Africa, where the devious offenders walked away without prosecution, created ripples that led many to rethink amnesty.

Much as the defenders of amnesty in South Africa argue that a peaceful transition at that time was more valuable, it created a history of scandal that within a space of approximately four decades some 8000 amnesty applicants and even a greater number that had not applied walked free of the grievous crimes they had committed. Also, the case of Peru where the political class legalised impunity in the name of amnesties, has led scholars such as Laplante to advocate the outlawing of amnesty as an immunity measure in transitional justice. ${ }^{26}$ With the tenet of amnesty conflicting with escalating international criminal and human rights laws, Dugard ${ }^{27}$ asks whether amnesty remains an option in today's transitional justice programme, and answers that with the development of international human rights and criminal laws it no longer is the proper price to be paid for truth. We also think it is not, especially the two categories of blanket and self-granted amnesties that award large-scale, if not complete, coverage to crimes. These categories of amnesty are unjust. There are compelling reasons to believe that the processes of truth commissions can be compromised at different points, and amnesty programmes provide suitable cover for it. An example is where the negotiations between Nelson Mandela and FW de Klerk were said to have produced the terms of agreement on which basis the Truth

BA Garner (ed) Blacks law dictionary (2009) 99.

Buck (n 10) 79-83.

Laplante (n 6) 983.

Dugard (n 23) 1001-1015. 
Commission proceeded. Here, it is possible that an individual's interest may supersede those of the group. Such a possibility demonstrates that broad-based amnesty is not such a good idea after all. Such amnesties seem to be the worst modern tools of diplomacy that re-victimise the victim and make the protection of human rights (in our context, the rights of victims) difficult.

\title{
5 Why compromising the justice component may scuttle the transitional justice process
}

\author{
According to Dugard,
}

[t]he present state of international law on the issue of amnesty is, to put it mildly, unsettled. While amnesty is prohibited in the case of genocide and war crimes committed in international armed conflicts, there are no clear rules prohibiting amnesty in the case of other international crimes. 28

Does this lack then mean that national governments are at liberty to award amnesty in all other areas, such as government repression, forced disappearances, widespread torture and imprisonment, systemic violations of rights of citizens, children and women, assassinations, executions, gang brutality, killings and violence, that are not committed during war time? A typical example may be the ongoing killings and destruction of property by Fulani headsmen in the middle belt and other parts of Nigeria.

It should be observed that one of the weaknesses of certain categories of amnesty in a modern society is trivialising accountability by neglecting the rule of law. Another is that it tramples on the rights of victims to justice. We observe here that any justice programme that does not punish the offender punishes the victim. What is meant here is that victims are entitled to reparation and, above all, to justice. They become twice victimised or punished by the justice system when perpetrators are not brought to account. The punishment they suffer is the psychological pain of the knowledge that their attackers have walked away free. It should be a cardinal requirement in transitional justice that criminals be brought to account. This may be called the principle of 'justice as inevitable reaction'. By this principle we conceive justice (retributive) as a reaction to offences. The laid-down laws of a society determine when an offence has been committed. Justice then becomes the maintenance of the rule of law. Justice reacts to restore any law that has been breached. In any modern society where laws have been enacted, whether those laws are obeyed or not, justice inevitably reacts when they are breached. However, what happens is that where the rule of law is maintained, justice reacts to punish the offender and where the rule of law is not maintained it reacts to punish the victim. The victim, therefore, becomes twice victimised. This situation leaves us to ponder whether in the long run 
amnesty contributes to building democracy, democratic institutions and a culture that respects human rights and the rule of law.

However, the ultimate factor that vitiates those truth commissions that offer amnesty during transitional justice is the possibility of compromising the rule of law. There are four possible stages of transitional justice, namely, the period of conflict where the abuses are committed; the period of negotiations on how to end the conflict and introduce peace; the period of fragile peace where justice was not served; and the period of enduring peace where justice is served. We may choose to colour these four stages which may be imperative to enable us to capture clearly the essence and the flaws which a transitional justice programme might suffer and the long-term consequence. Find below the labelling and interpretation of the various stages of transitional justice. We wish to clarify that our interpretation of colours in this theory is not based on racial definition.

\section{Figure 1. Colour representation of the moods of transitional justice}

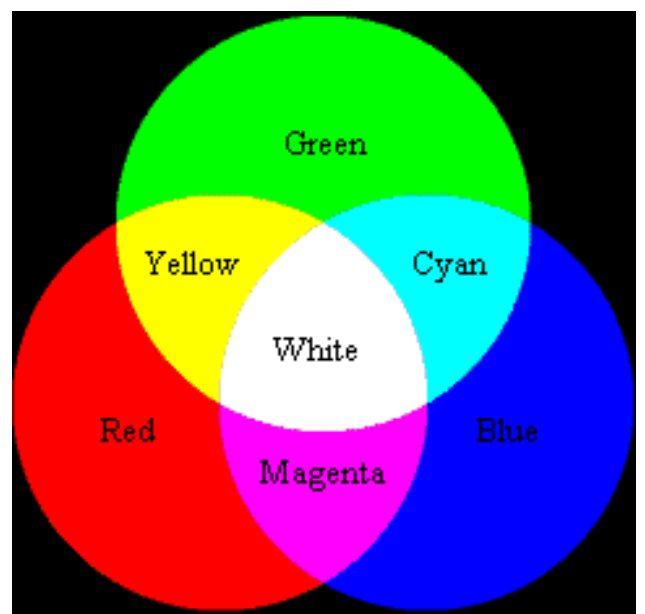

Source: Wolfstone Group 'Colour Mixing', http://209.150.104.225/Lighting/ colmix_ColorMixing.html

In the above figure, three primary colours, red, blue and green when mixed, form different shades of colours: Red + blue = magenta; blue + green = cyan; green + red = yellow; red + blue + green form white. In the four stages of a transitional justice process identified above there are moods, and we will identify some such possible moods and label them with the colours in the above figure. The first is the mood of crimes and abuses (red); fragile peace (blue); long-term peace (green); negotiation with little or no compromise (yellow); negotiation with serious compromise (magenta); damage control (cyan). Let us consider white as a neutral mood in which the interests and mind sets of the negotiators are upright. In this condition, the 
negotiating corridor is transparent and compromises are averted. As a product of red + blue + green, which depicts the moods of the acknowledgment of the conditions of crime (red), the possible outcome of fragile peace (blue) if there are compromises and the possible outcome of long-term peace (green) if compromises are averted.

\section{Figure 2. Colour interpretation of the moods of transitional justice}

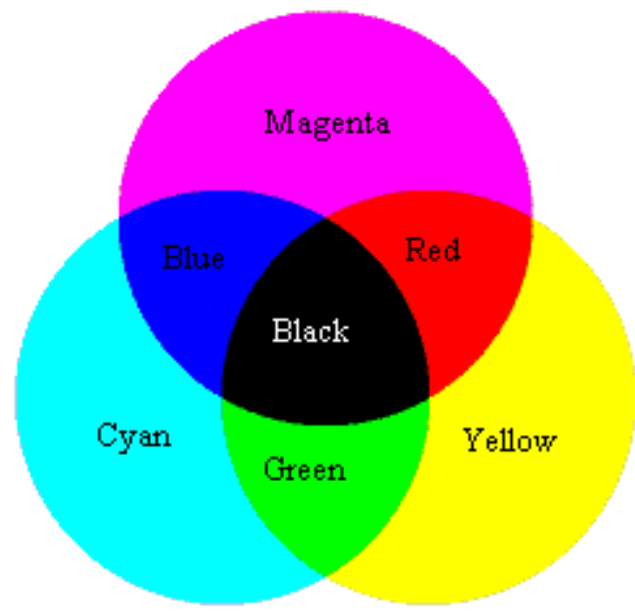

Source: Wolfstone Group, 'Colour Mixing'. http://209.150.104.225/Lighting/ colmix_ColorMixing.html

Let us interpret the above figure with the labelling in figure 1 . Negotiation with little or no compromise (yellow) + negotiation with serious compromise (magenta) will ultimately regress to the mood of crimes and abuses (red). The mood of damage control (cyan) + negotiation with serious compromise (magenta) will lead to fragile peace (blue). The mood of negotiation with little or no compromise (yellow) + the mood of damage control (cyan) will lead to long-term peace (green). However, when the mindsets and interests of negotiators vary proportionately in the structure of damage control (cyan) + negotiation with serious compromise (magenta) + negotiation with little or no compromise (yellow), the negotiating corridor will be clouded in dark secrecy within which compromise becomes possible.

The success or failure of transitional justice to a large extent depends on whether negotiations for a way forward were compromised. During negotiations a number of actors are involved, notably perpetrators; accomplices; interest groups; beneficiaries; loyalists; affiliates; speculators; opposition; power blocs; foreign bodies; governments; and so forth. One truth is that these actors all have interests. The interests of these actors may vary considerably, but 
in some ways it may be possible to reconcile some of these interests. This is where compromise sets in. We briefly outline five possible points of compromise below:

(1) Beneficiary factor: There are people who benefit in conflict situations and during the transition process. ${ }^{29}$ These include arms suppliers, business men who trade on illegally-obtained national resources such as blood diamonds in Sierra Leon, blood crude oil in the Middle East, Libya and the Niger Delta of Nigeria, and so forth. These people will do everything to compromise a transitional justice process to see that the eventual outcome will be more conflict or at least a fragile peace.

(2) Legal disability factor: When the rule of law is not first established, negotiators will operate in an atmosphere of unmonitored freedom. Anything therefore is possible during this process of negotiations. Different groups and individuals with selfish interests might enter deals that compromise the process.

(3) Commitment factor: Perpetrators of heinous crimes during repressive times usually have loyalists, affiliates, associates and accomplices who owe them favours. The perpetrators try to get these unknown accomplices to the negotiating room where they seek to approve policies and measures that protect the interests of the perpetrators. This is another way in which the process could be compromised.

(4) Speculator factor: People with selfish motives will seek to conclude dirty deals. In a corrupt and repressive regime, for example, actors acquire great wealth and property. There might be members of the negotiation team who might want to do back deals with the perpetrators to receive a chunk of the stolen wealth and property in order for them to support or propose amnesty. These people do not care about peace and stability; they are property speculators who want to have their own share. Once their demands have been met by the perpetrators, they become complicit and as such seek to compromise the process.

(5) Spaceship factor: This is also called the parachute effect. ${ }^{30}$ It explains the way foreigners participate in transitional justice initiatives. They simply come in, sometimes not fully enlightened about the nature of the conflict and motives of local agents they are to work with, and as soon as they have completed their mission they leave without any follow-up programme. This paves the way for the implementation programme to be compromised at certain points, which may eventually retard the growth recorded earlier in the programme.

We thus infer that sometimes, when any of these factors compromises the negotiations or any other phase of a transitional justice

29 Sooka (n 13) 313.

30 Sooka 314. 
programme, immunity measures such as amnesty become an important part of a truth commission and concepts such as confession, remorse, forgiveness, reparation, peace and reconciliation are emphasised. The South African case is a good example. Schabas tells us how the private agreements between Nelson Mandela and FW de Klerk shaped the transitional justice process in South Africa. ${ }^{31}$ Another example is that of the Democratic Republic of the Congo (DRC) where Sooka reports that a truth commission was established while the conflict was still ongoing and under pressure from peace brokers: 'The commission itself has members who are associated with warring parties and, as such, do not qualify as impartial.' Sooka then asks: 'Under these circumstances, can such a commission function with credibility?'32 Yet another example is when truth commissions begin by announcing amnesties. Sooka suggests that this may weaken their resolve to eventually prosecute some severe cases and the outcome is an embittered victim, especially 'the victims who feel the commission benefited perpetrators'. Thus, Sooka cautions that '[i]n establishing a truth commission, although healing and reconciliation are important, justice for victims should be given priority by ensuring that it is part of its core mandate'. ${ }^{33}$ Also, Laplante gives two examples about outgoing dictators such as the Chilean Augusto Pinochet and Peruvian President Alberto Fujimori who used amnesty to provide cover for the crimes committed by their regimes. ${ }^{34}$ Also, Hayner cites a number of cases such as in Liberia where the members of the truth commission were arbitrarily chosen by the government in power without due process, thereby casting doubt on the commission's credibility. 35

Wilson suggests that these forms of compromise are easily recognised when the language of reconciliation becomes hegemonic as in the South African case. ${ }^{36}$ Klaaren and Varney further suggest that in such a compromised transitional justice process, talk of reconciliation displaces that of criminal prosecution and is placed on the front burner in the process. ${ }^{37}$ On the other hand, when the negotiation is not compromised or not seriously compromised, criminal prosecution tends to feature in a truth commission and concepts such as justice, human rights, punishment and the rule of law are emphasised. We must admit that the latter is difficult to

31 W Schabas 'Transitional justice and the norms of international law' Presented at the annual meeting of the Japanese society of international law, Kwansei Gakuin University (2011) 11-12.

32 Sooka (n 13) 312.

33 Sooka 316-317.

34 Laplante (n 6) 919924944.

35 Hayner (n 18).

36 Wilson (n 21) 171.

37 J Klaaren \& $H$ Varney 'A second bite at the amnesty cherry? Constitutional and policy issues around legislation for a second amnesty' (2000) 117 South African Law Journal 572 581-592. 
achieve without a transparent negotiation phase that establishes the rule of law.

\section{Towards a rule of law-based alternative}

It is clear from our discussion that what is lacking in some transitional justice programmes that accommodate certain categories of amnesty is the element of retribution. What our rule of law-based alternative compels the state and peace brokers to do is to establish an inviolable benchmark for the transitional justice programme in which accountability by way of criminal prosecution becomes not only a feature but a strong and prominent component. This rule of lawbased proposal is the moral twine binding our ideas together, as becomes apparent when the question is asked whether one would rather leave the victim dissatisfied irrespective of the argument or have the offender deservedly punished. Punishing the offender not only is the legally correct thing to do, but is the morally right course of action. However, this practice entails the establishment of the rule of law as the foremost step in a transitional justice programme. In a way, we envision that this will affect the structure of truth commissions that have become the central nervous system of transitional justice programme, because amnesty, which is an essential part of truth commissions, would be limited to crimes a reasonable human considers not serious or outlawed. In this connection, Laplante argues that

[m]any scholars now acknowledge that to be legitimate, amnesties must conform to legal norms. This has created a standard of 'qualified amnesties' with customary and treaty law prohibiting bars to prosecution for war crimes, enumerated treaty crimes, and crimes against humanity ${ }^{38}$

as truth commissions seek to do through amnesties.

Even though Hayner contends that 'it is not correct to say that most truth commissions provide political cover for amnesties, as some analysts have suggested, or that most truth commissions are established along with an amnesty', 39 records from most truth commissions bear witness to a preference for amnesty to criminal prosecution. The point need not be stressed again that in volatile times peace is regarded as more important than the rule of law, as truth is more important than justice. At least, that has always been the defence mounted by advocates of truth commissions and amnesty, which crystallises in what is called the 'truth versus justice debate'. This debate seeks to establish which is better, truth that could lead to peace and stability or justice that could lead to further escalation of conflict. Our take on this debate is that the suggested moral dilemma was mischievously created or simply does not exist. One can reach the

38 Laplante (n 6) 918.

39 Hayner (n 18) 105. 
truth without awarding broad-based amnesties as the Nuremberg trials prove. In difficult cases, for example, a conditional amnesty that covers witnesses and accessories is adequate to reach the truth and prosecute perpetrators.

Modern society claims to rest on the rule of law. As the social contractarians point out, a state is a product of a pact. People come together to submit their individual freedoms and enact for themselves a body of laws to regulate their actions. Thus created, the state owes a range of debts and duties to its citizens which it is under obligation to honour. What this view implies is that any state that fails to honour these debts and duties (which are within its capacity to pay) automatically loses its moral authority to regulate the actions of its citizens.

A study of modern political theory reveals that the fundamental index of a functional society is the rule of law. Kelly ${ }^{40}$ explains that streamlining a political process that led to the emergence of the nation state in the nineteenth century was a test of the rule of law in which the idea of the modern state as a political entity is that which owes no allegiance to any other power above itself. It is on the basis of the rule of law as the first principle of any modern state that political philosophers such as Hobbes, Locke, Rousseau, Hegel and Mill formulate theories on how best to maintain, promote and apply the rule of law.

Transitional justice cannot yield long-term stability if the component of the rule of law is compromised. Therefore, it is our proposal that transitional justice be redesigned to have the rule of law as its backbone and to outlaw certain categories of amnesty that shield perpetrators of serious crimes from prosecution. This rule of law-based alternative stipulates that the United Nations General Assembly be empowered to temporarily set aside a state's sovereignty and establish the rule of law in any troubled context using international forces prior to any negotiations that will lead to a transitional justice programme. This piece of legislation may be called the 'frozen sovereignty proviso'. This legal provision in international law would especially be required to discourage would-be dictators and tyrants from orchestrating human right abuses. Granted that this concept creates room for the intimidation of some states by others at the international level, it remains our best option for curtailing the impunity taking place in some states in modern times. It is easier for a tyrannical element in a state to initiate a programme of massive human rights abuses than for the majority of states in the UN General Assembly to conspire against a state. What is called for, however, is a careful articulation of the 'frozen sovereignty proviso' fitted with relevant clauses that will drastically reduce the room for abuse. Despite the great strides that in recent decades have been made in

40 P Kelly Introduction to modern political thought Undergraduate study guide, international programmes, University of London (2011) 6. 
international law, legislation such as the 'frozen sovereignty proviso' remains conspicuously absent.

On the one hand, stable states might not broach the idea of such a proviso because of the fear of being accused of imperialism and neocolonialism. On the other hand, non-stable states relish the cover which the provision of inviolable state sovereignty provides to immunise them against external interference in their dirty business. Rawls in his The law of peoples intuits that stability and security at the national level will determine stability and security at the international level. ${ }^{41}$ While not denying this possibility, we are of the view that a more practical alternative will be a situation where stability and security at the national level are guaranteed at the international level through laws such as the 'frozen sovereignty proviso'.

The modern world has made significant progress in terms of the quality of national laws. It has also made advances in the area of international law, but has not replicated at the international level the type of progress made at the national level. There is an apparent use of kid gloves in regulating nation states, made possible by the notion of state sovereignty deemed to be inviolable. It is understood that the events of World Wars I and II make this provision necessary, and some minor adjustments could still be made for the good of all. Sanctions of all kinds may be effective, but experience has shown that it is usually the innocent citizens that suffer, as in the cases of North Korea, Iran, Venezuela and Zimbabwe, to mention but a few. A provision that empowers the world body to temporarily set aside a state's sovereignty in the event of massive human right abuses would help avert horrendous incidents such as the Biafran genocide of 1967-1970 and the 1994 Rwandan genocide, to mention but a few examples. We are convinced that the 'frozen sovereignty proviso' or anything like it will constitute an important chapter in international law.

The successful enactment of the 'frozen sovereignty proviso' will strengthen criminal prosecution rather than broad-based amnesty and make it an important aspect of transitional justice. According to Naqvi, '[c]riminal prosecution of those accused of committing war crimes is a fundamental aspect of a victim's right to justice' ${ }^{42}$ The author, however, proceeded to state that the incorporation of what the author calls 'limited amnesties' might be tolerated in a transitional justice process, and we are not opposed to this idea. In the tightening of international human rights and criminal laws, Laplante is correct in arguing that 'we can glimpse the impending demise of amnesty'. ${ }^{43}$

41 J Rawls The law of peoples: With the idea of public reason revisited (1999).

42 Naqvi (n 20) 583.

43 Laplante (n 6) 932. 


\section{Conclusion}

In this article we have articulated some concepts and principles to advance a rule of law-based alternative to broad-based amnesty in a transitional justice process. We submit that the best possible programme of transitional justice would be one in which the rule of law is pre-established through an international law provision to protect the rights of victims and have the state honour its debts and duties to its citizens during the process. The claim that justice will trigger violence and lawlessness, as widely speculated in the case of South Africa, is unfounded and mischievous if the rule of law was first established in a transitional justice process covering four possible stages and six moods, as colour-charted in the figures above. Our proposals are for truth commissions and, by extension, transitional justice programmes, to be fitted with criminal prosecutions as their central component and to limit amnesty to crimes which a reasonable human being would describe as not severe. The essence of prosecuting and punishing offenders in a modern state where the rule of law reigns is to protect the rights of victims, to honour the debts and duties of the state to its citizens, and, most importantly, to maintain the statehood of a state by preventing it from becoming a rogue state or, worse still, a failed state. 